\title{
Genetics and ethics in Latin America
}

\author{
Jorge Sequeiros $^{1} \cdot$ Sahra Gibbon $^{1} \cdot$ Angus Clarke $^{1}$
}

Received: 14 May 2015 / Accepted: 18 May 2015 / Published online: 9 June 2015

(C) Springer-Verlag Berlin Heidelberg 2015

\section{Why "genetics and ethics in Latin America"?}

If genetics has shown, at the same time, the enormous wealth of human variability and the scarcity of their genetic differences (which can be much less between very distinct populations than between two persons from the same population), prejudice and racism are still there, difference is not always well accepted, and human rights of individual persons or entire populations continue to be violated throughout the world.

Genetic forms of determinism and reductionism, as applied to behaviours and personality, accompany and generate contempt for the disadvantaged and lead to the abandonment of policies to combat social inequality, poverty, hunger and crime. Genetics, as any other science, is not neutral. On the one hand, it has been used to build pseudo-scientific theories legitimising racism, colonialism, eugenics and ethnic genocides. On the other hand, however, it has also shown its extreme usefulness in the defence of human rights, from the identification of the remains of missing persons to the restoration of genetic identity of children of political prisoners who were appropriated by supporters of dictatorial regimes and state terrorism, often after their parents had been murdered. The long and the recent history of Latin America bring these starkly to the fore (Sequeiros 2012).

In Latin countries (on both sides of the Atlantic), there were eugenic associations and movements for "purity of race" (closely

This article is part of the special issue on "Genetics and Ethics in Latin America".

\section{Jorge Sequeiros}

jorge.sequeiros@ibmc.up.pt

1 Instituto de Biologia Molecular e Celular (IBMC), Universidade do Porto, Porto, Portugal linked to fascist regimes and the various dictatorships endured in many of those countries), which defended the concept of "inferior peoples". These theories legitimised "conquest" and the genocide of indigenous peoples, justified colonialism and slavery, and helped in creating societies based on "pigmentocracy".

\section{History of human and medical genetics in Latin America}

As in many other countries and continents, Latin American naturalists, botanists and physicians became interested in Mendel's theory of heredity and Darwin's theory of evolution and began active teaching and research in genetics, in the first few decades of the 20th century. As Cruz-Coke (1999) notes, during the thirties and forties, several North American geneticists visited South America and helped developing research centres in cytogenetics and population genetics, in Brazil and Argentina. In the fifties and sixties, human genetics became properly established in Brazil, Argentina and Chile.

In 1955, the Brazilian Society of Genetics was founded. The Latin American Genetics Society (ALAG) was created in 1969, promoting scientific exchange amongst zoologists, botanists, physicians and anthropologists. Latin American scientists made great contributions in animal, plant and human genetics, exploring the great genetic diversity of the continent and reporting new genes and diseases. "In 1997, there were 130 medical genetics centres, 120 hospitals specialised in congenital malformations, 56 molecular biology centres and 26 molecular genetics centres" (Cruz-Coke 1999; see also Penchaszadeh and Beiguelman 1998).

The first pioneers of genetics in Latin America included Sáez and Horowitz, in Argentina, who started cytogenetics studies of insects and pollen, respectively, in 1925 and 1926; in Brazil, Dreyfus and Pavan started studying evolution in 
Drosophila in 1943, whilst Salzano initiated the study of polymorphism in Drosophila in 1950; in Chile, Cortázar began his research on wheat and its hybrids in 1947; many others followed in other countries, during the second half of the 20th century. In medical genetics, Morquio studied the mucopolysaccharidoses, in 1929, in Uruguay. For further information, see Tables 2 and 3 of Cruz-Coke (1999).

Several strong transnational collaborations began at those times (Dronamraju 1992). In the thirties, McClung and Stebbins, cytogeneticists from the USA, visited Argentina; in 1943, Dobzhansky arrived in Brazil, where he played a crucial role in developing the first genetics centre there, at the University of São Paulo (with Dreyfus, Krug and Pavan). Later, Neel associated with Salzano (of the Universidade Federal do Rio Grande do Sul, Porto Alegre) to begin studying indigenous populations in Latin America, whilst Morton joined Krieger in the study of populations and evolution. Brazil then became a solid centre for the development of human and medical genetics in Latin America.

Several Latin American pioneers studied in the USA, with McKusick, Motulsky, Schull, Gardner and Crow; they studied in the UK, with Penrose, Fraser, Roberts, Stevenson, Kalmus, Race and Sanger; they studied in France, with Lamy, Lejeune, de Grouchy, Frezal, Dausset and Monod; they studied in Italy, with Gedda, Cavalli-Sforza, Barrai and Milano; they studied in Germany, with Becker, Vogel, Lenz and Patau; and they studied in Spain, with Ochoa and Lacadena (Dronamraju 1992). This has also fostered the development of cytogenetics, along with biochemical, molecular and clinical genetics, in the sixties and seventies. It is notable that some countries in Latin America recognised the specialty of clinical genetics before many European and other countries.

RELAGH (the Latin American Network of Human Genetics) was created in 1997 and fostered the creation of the Latin American School of Human and Medical Genetics (ELAG) in 2005 [see Giugliani et al. this issue. doi:10.1007/s12687-015-0230-8].

\section{Ethical challenges (and opportunities) of human genetics in Latin America}

Human and medical genetics have always raised important, indeed burning, bioethical issues, from Asilomar to the $\mathrm{Hu}$ man Genome Project. On the other hand (unlike, e.g. quantum physics), the public perception of genetics places it at the very centre of life. Genetic information is sensed as particularly intimate and embedded in communities and social life. This needs to be considered in the context of the informed consent process, for both medical and research activities, and the establishment of clinical and research ethics committees, at hospital and academic institutions.

As elsewhere, the relation between ethics and science is not a simple one, as discussed by Salzano [this issue. doi:10.1007/ s12687-014-0211-3], who coins here the term geneticophobia. The history of bioethics in Latin America shows, however, some differences and deviations from those of, e.g. AngloSaxon counties, as shown by Goldim [this issue. doi:10.1007/ s12687-015-0232-6], who discusses these national differences, as well as those within Latin America. These articles present a different perspective on the controversy that either sees ethics as a barrier to the advance of science or recognises the need for oversight of research by regulation and guidelines, through a system of ethics committees and by the society at large.

Two issues of particular importance in Latin America are the ethics of genetics research amongst native and mixed populations [Minaya and Roque this issue. doi:10.1007/s12687015-0240-6, also covered by Salzano this issue. doi:10.1007/ s12687-014-0211-3] and the recovery of identity by children appropriated in various Latin American countries during ruthless dictatorships [Penchaszadeh this issue. doi:10.1007/ s12687-015-0217-5] as well as by families separated due to compulsory isolation in leprosaria [Schuller-Faccini et al. this issue. doi:10.1007/s12687-015-0236-2].

Adequate informed consent (both at the individual and community level) is also not seen the same way everywhere and in every culture [Minaya and Roque this issue. doi:10. 1007/s12687-015-0240-6]. Goldim and Gibbon [this issue. doi:10.1007/s12687-015-0234-4] discuss the issues of personal and relational privacy and the process of informed consent in the context of cancer genetics, whilst Ashton-Prolla et al. [this issue. doi:10.1007/s12687-015-0238-0] approach the challenges of informed consent posed by whole genome/ exome sequencing and the benefits and challenges of these new techniques for health care professionals and patients.

Social inequalities, as they are manifested in Latin America, necessarily create barriers in access to genetic services, which may tend to increase as technology advances and generate new health care services and interventions [Gusmão Melo et al. this issue. doi:10.1007/s12687-015-0224-6].

\section{Genetics, ethics and legislation}

In Latin American countries, regulatory frameworks of genetics and genetic services are often rather different from those in other countries, though there is also a wide variability within Latin America itself. Bergel [this issue. doi:10.1007/s12687015-0228-2] examines the conceptual differences between industrialised and Latin American countries regarding the patentability of human genes.

Gusmão Melo et al. [this issue. doi:10.1007/s12687-0150224-6] present the public policies concerning the integration of genetics into primary health care and the National Policy on Comprehensive Care for People with Rare Diseases in Brazil, including issues of reimbursement and the inequalities in access to genetic services within the national health system (SUS). 
Rojas-Martinez [this issue. doi:10.1007/s12687-015-02335] discusses the vulnerabilities created by the Genomics Sovereignty Act in Mexico concerning confidentiality and data sharing, whilst Fernandes et al. present the legal perspective in Brazil about genetic information and biobanking [this issue. doi:10.1007/s12687-015-0242-4].

\section{Genetic services and public health genetics}

The different regulatory frameworks outlined in these papers reflect on the disparities and differences in the provision of genetic services within Latin America itself. The Latin American Registry of Assisted Reproduction (RLA) was established in 1990, as the first multinational and regional registry collecting data on assisted reproduction technologies (ART) (Zegers-Hochschild et al. 2012). Preimplantation genetic diagnosis (PGD) is practised (though not necessarily regulated) in several countries. Unfortunately, the RLA does not distinguish between PGD and PGS (the preimplantation genetic screening for aneuploidies, not for genetic reasons, but to increase success rates in ART) and records them together: 74 centres from Argentina, Brazil, Chile, Colombia, Mexico, Panamá, Peru and Venezuela described 1664 cycles (20 polar body biopsies, 65 biopsies of cleaving-embryos and 1579 PGD/PGS biopsies in blastocysts). "Overall, 708 embryo transfer cycles were carried out. Out of 264 clinical pregnancies and 218 deliveries, a total of 252 babies were born; none of which was reported as having birth defects" (ZegersHochschild et al. 2012).

According to the Centre for Reproductive Rights (2014), termination of pregnancy (TOP) is permitted by law without restriction, during the first 12 weeks of pregnancy, only in Uruguay and Mexico City (DF); it is also allowed up to 14 weeks, if the pregnancy results from rape, and for severe congenital anomalies, in Uruguay and for unviable foetuses, in Mexico City (DF). In all other Latin American countries, it is either not permitted at all or allowed only with severe restrictions. Permissible reasons for TOP in Colombia include danger to the life or physical or mental health of the mother, rape, incest and unviable foetuses; in Argentina, when the pregnancy poses a threat to the health or life of a woman, or results from the rape of a woman with a mental disability; in Brazil, to save the woman's life, when the pregnancy results from rape and when the foetus is affected by anencephaly. Peru has national guidelines on the provision of abortion services in health facilities. This necessarily leads to the unavailability of prenatal diagnosis or undermines its purpose and has other repercussions, such as illegal abortion and perpetuating social inequalities [Penchaszadeh this issue. doi:10.1007/s12687-015-0219-3; Landaruburu et al. this issue. doi:10.1007/s12687-015-0236-2].

Penchaszadeh [this issue. doi:10.1007/s12687-015-0219-3] also debates other ethical issues related to genetics and public health in Argentina, as compared to other Latin American countries. Bidondo et al. (2015) presents the public health approach to birth defects in Argentina.

Landaruburu et al. [this issue. doi:10.1007/s12687-0150236-2] discusses the public policies in Uruguay regarding genetics and ethics, using the national newborn and infant screening programme as a paradigm. Whilst Cruz-Mariño et al. [this issue. doi:10.1007/s12687-015-0226-4] explain the predictive testing programme for spinocerebellar ataxia type 2 (SCA2), in Cuba, Cornejo-Olivas et al. [this issue. doi:10.1007/s12687-015-0239-z] describe the development of neurogenetics in Peru, comparing it to other Latin American countries, and Marinho et al. [this issue. doi:10. 1007/s12687-015-0235-3] present their results of pre-test interviews in a cohort of Brazilian patients with movement disorders. The viewpoint of physicians providing genetic consultations and the challenges for genetic counselling in Colombia are approached by Rodas-Perez et al. [this issue. doi:10.1007/ s12687-015-0237-1].

Thus, several authors and research groups from various countries in Latin America (Mexico, Colombia, Cuba, Peru, Brazil, Uruguay and Argentina) contributed to this special issue. Many have long careers in the field and have established an international reputation in their respective fields, from biomedicine to the social sciences, including medical and nonmedical geneticists, bioethicists and human rights lawyers. This special issue also demonstrates the value of such a cross-disciplinary and comparative perspective, when addressing some of the many complex issues at the interface between genetics and ethics.

\section{References}

Bidondo M, Groisman B, Barbero P, Liascovich R (2015) Public health approach to birth defects: the Argentine experience. J Community Genet 6:147-156

Centre for Reproductive Rights (2014) Abortion worldwide: 20 years of reform. Available at: www.reproductiverights.org/sites/crr. civicactions.net/files/documents/20Years_Reform_Report.pdf; accessed on: 14 May 2015

Cruz-Coke MR (1999) Historia de la genética latinoamericana en el siglo XX. Rev. méd. Chile 127:1524-1532. Available at: www.scielo.cl/ scielo.php? script=sci arttext\&pid=S 0034 98871999001200016\&lng=es; accessed 13 May 2015

Dronamraju KR (1992) History and development of human genetics. World Scientific, Singapore, 1992 [cited by Cruz-Coke MR 1999]

Penchaszadeh VB, Beiguelman B (1998) Medical genetic services in Latin America: report of a meeting of experts. Rev Panam Salud Publica 3:409-420

Sequeiros (2012) La genética y los derechos humanos. In: Penchaszadeh (ed.) Genética y derechos humanos: encuentros y desencuentros. Buenos Aires, Paidós

Zegers-Hochschild F, Schwarze JE, Crosby JA, Musri C, de Souza MCB (2012) Assisted reproductive technologies (ART) in Latin America: the Latin American registry, 2012. JBRA Assist Reprod 18:127-135 